Thorax (1956), 11, 334.

\title{
INTRATHORACIC MENINGOCELE
}

\author{
BY \\ J. C. A. RAISON \\ From the Thoracic Surgical Unit, King Edward VII Memorial Chest Hospital, Warwick
}

(RECEIVED FOR PUBLICATION APRIL 9, 1956)

The diagnosis of intrathoracic meningocele, lying primarily in the paravertebral gutter and radiologically resembling a neurofibroma, has been said to be easy if the existence of the condition is previously considered. In view of the rarity of the condition, however, it is understandable that in many of the cases described the diagnosis has been made unexpectedly at operation or necropsy. Apart from a mention by Groedel (1936) in a textbook of radiological diagnosis, intrathoracic meningocele has not found a place in any major works of radiology or thoracic disease. An extensive study of hourglass tumours by Heuer (1929) and that by Schmorl and Junghanns (1932) describe only solid intrathoracic tumours. A wide review of the literature upon spina bifida by Ingraham and others (1944) likewise did not include thoracic meningocele. Twenty-six cases have received mention in the world literature, not all of them fully documented. Two further cases are now presented, one being of particular interest, having been discovered at about the time Pohl (1933) first described the condition.

\section{CASE REPORTS}

CASE 1.-H. B., a healthy male postal superintendent, aged 39 , was found to have a neurofibroma-like shadow in the right hemithorax at mass miniature radiography. He was entirely asymptomatic. He had never had a chest radiograph before this. There was no relevant previous medical history. The patient was admitted to the Thoracic Surgical Unit, Warwick. on December 1, 1954. There was no evidence of von Recklinghausen's disease superficially, nor of café-au-lait spots on the skin. Skeletal development was normal. There was no family history of cutaneous neurofibromatosis or of congenital bony deformity. There was no history of severe trauma. Physical signs were normal in the chest and abdomen. A full neurological examination was carried out and no abnormalities shown. The patient denied any pains or any recurrent chest infections. A radiograph of the chest (Fig. 1) showed a fairly welldefined, apparently solid opacity in relation to the eighth and ninth vertebral bodies in the right hemithorax. A lateral film showed enlargement of the intervertebral space on the right side between these bodies, but no other abnormality. Lateral tomography suggested a central area of radiotranslucency in the mass. It was considered to be a neurofibroma with possible cystic degeneration. Penicillin, 500,000 units intramuscularly b.d., was begun on December 2, 1954.

Right thoracotomy was performed on December 3. the mass being approached transpleurally. The lung was free. Parietal pleura covered a slightly pulsating tumour and this was carefully divided, exposing a meningocele about 6 by 4 by $4 \mathrm{~cm}$. lying along the paravertebral gutter in relation to the eighth and ninth vertebral bodies and having a neck protruding from the intervertebral space. It was dissected without great difficulty down to its neck. The foramen was seen to be widened circularly to about $3 \mathrm{~cm}$. diameter, roughly twice normal. The meningocele was opened, cerebrospinal fluid ran out, and the spinal cord was seen clearly through the neck of the sac, which was then plicated with thread, leaving sufficient of the neck to obtain good closure. The neck retracted into the intervertebral foramen. The associated intercostal nerve was seen running in a normal manner above the meningocele and dissociated from it. A portion was removed for examination. The parietal pleura over the site was resutured, and the chest closed with nylon and catgut without drainage. There was very little haemorrhage. The patient was nursed flat for 12 hours and then gradually allowed to sit up. He did not complain of headaches at any time, was allowed up on the fifth day, chemotherapy was discontinued on the tenth day, and he was discharged home on the fourteenth day. A radiograph taken seven weeks after operation shows no recurrence of the lesion. Fifteen months later the patient is well, working, and there is no radiological recurrence (Fig. 2).

Pathological examination of the cyst showed it to be a dural meningocele. No nerve tissue was found, nor was there evidence of a degenerating neurofibroma. The portion of intercostal nerve examined showed normal histology.

CASE 2.-Miss L. B., aged 46, an Irishwoman, was well until January, 1933, when she had a mild pyrexial upper respiratory infection lasting five days. After convalescence at the seaside abnormal physical signs were found in the chest and she was referred for radiography. The only other relevant history was that for several years she had been aware of slight 


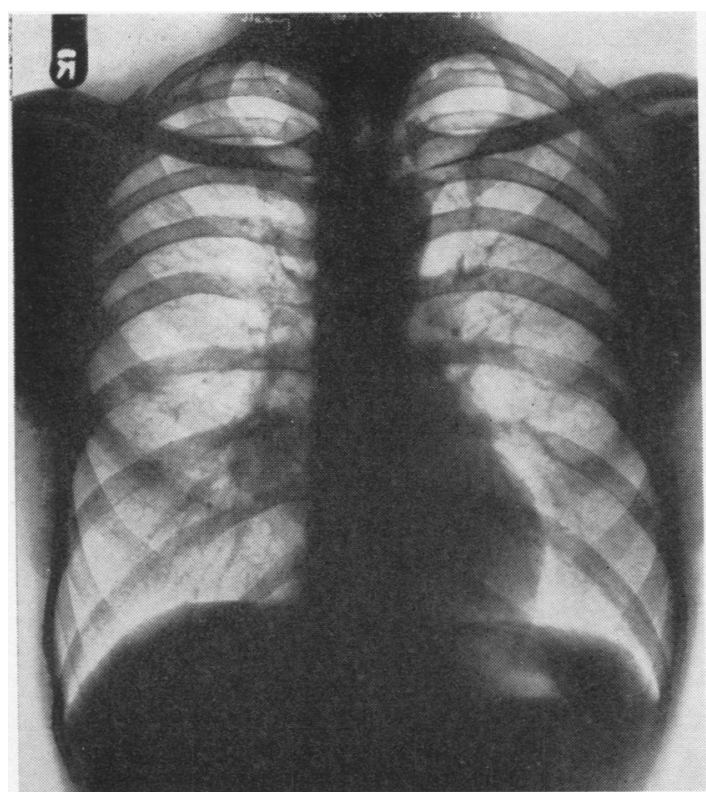

FIG. 1a.-Case 1: Pre-operative postero-anterior view showing rounded mass in right hemithorax.

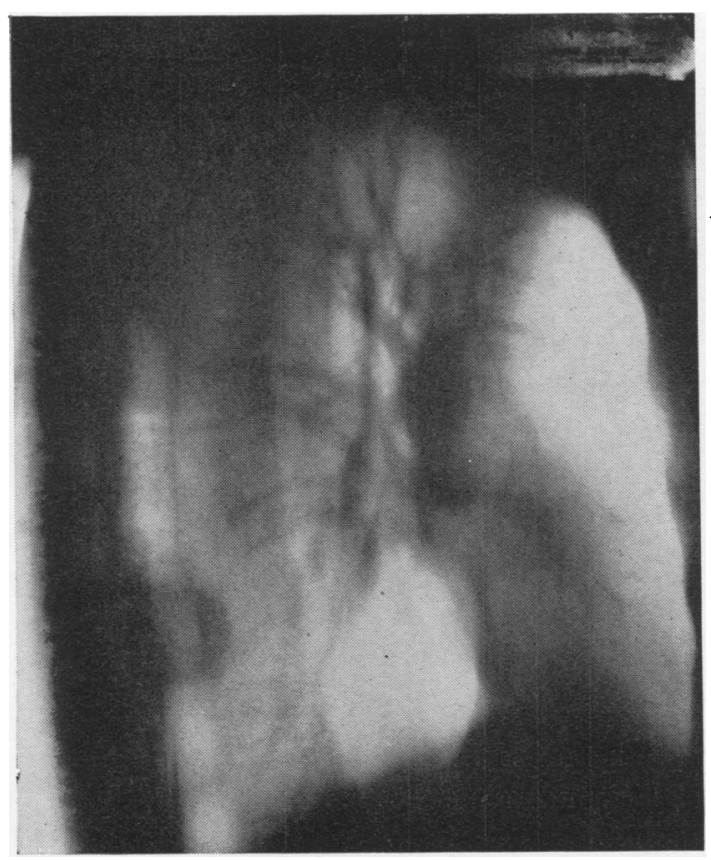

Fic. 1c.-Case 1: Tomograph showing relative radiotranslucence of central portion of mass.

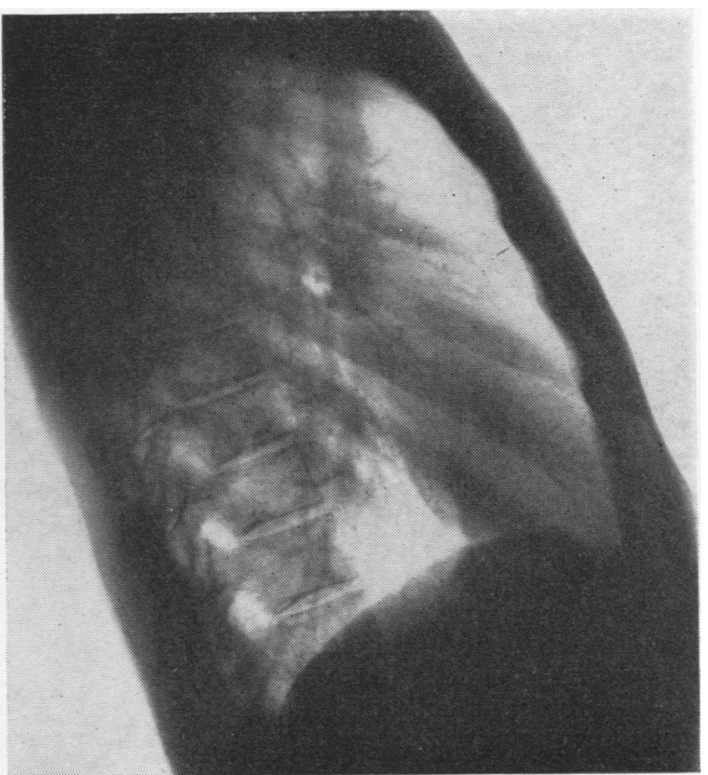

FIG. 1b.-Case 1: Right lateral film showing enlargement of eighth thoracic intervertebral foramen.

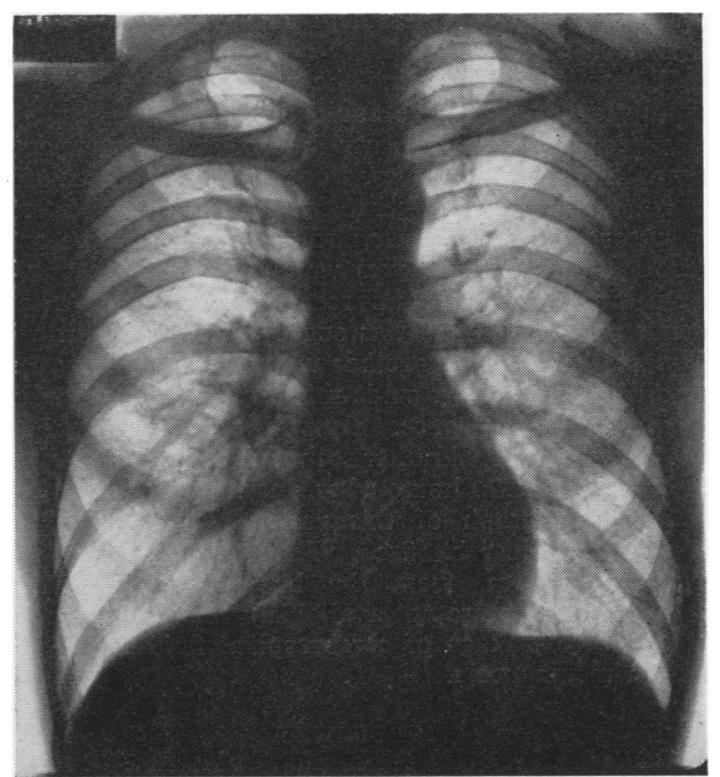

Fig. 2.-Case 1: Post-operative postero-anterior view 15 months after excision of meningocele. 
"vague pains" in the left infrascapular region. The right eye had been removed at 5 years of age for a congenital lesion of the face and eye, possibly an angioma. She was otherwise healthy. The radiograph is reported as showing a shadow in the left hemithorax, lying posteriorly and occupying its upper third, the edges fairly well defined. There was deformity and erosion of the third and fourth ribs posteriorly. She was admitted to the Biompton Hospital for Diseases of the Chest, London, on June 29, 1933. On examination, many small sessile skin tumours, ranging from pin-head to small pea size, were found. Biopsy of one of these was said to show a fibroma. Blood pressure was $150 / 90 \mathrm{~mm}$. $\mathrm{Hg}$. Cardiovascular, central nervous, and skeletal systems were normal. There were no abnormal abdominal findings. A left artificial pneumothorax was induced as a diagnostic measure. This confirmed that the mass was extrapulmonary.

Left thoracotomy was carried out on July 15 through " a much atrophied fourth rib." A cystic tumour, soft, and adherent in the costo-vertebral groove, was found. This was aspirated, and $8 \mathrm{oz}$. of perfectly clear colourless fluid withdrawn. The cyst proper appeared to consist of a single membrane inside a pink, very vascular capsule. It was dissected out gradually until it only remained adherent in the region of the vertebral column, the bodies of the adjacent vertebrae being much eroded. A considerable amount of tissue, which appeared to be the capsule, was left behind, especially above. The chest was closed without drainage. Blood loss was "free" during operation and the patient's condition afterwards was poor. Blood transfusion considerably improved this.

The following morning the patient was considered unduly drowsy, but she could be roused. The pulse was feeble in the left arm but of good volume in the right. She was of good colour. All tendon jerks were markedly exaggerated but equal. Bilateral extensor plantar response and ankle clonus were present. Abdominal reflexes were absent. The pupils were small, central, and reacted to light. A left facial nerve weakness was suggested, but the drowsiness of the patient, together with the asymmetry due to old facial surgery, made this a difficult observation of doubtful significance. Respiration ceased in a few hours, was restarted rather feebly, and the patient died in coma about 24 hours after operation.

(The radiograph of this patient is not available, having been lost by fire. The report is compiled, largely verbatim, from the hospital notes. Postmortem findings are not available.) Death was probably due to leakage of cerebrospinal fluid at the site of the meningocele.

\section{Discussion}

Intrathoracic meningocele, associated with multiple cutaneous neurofibromatosis, was first described by Pohl in 1933 ; a 47-year-old woman with a right-sided lesion was treated surgically by excision and myeloplasty, after which she died from an empyema. Further cases were described by Schüller and Uiberall (1938) and Ameuille Wilmoth, and Kudelski (1940). Death followed neurectomy in the former instance, a 56-year-old man with a right-sided meningocele treated by neurectomy for thoracic pain, and, in the latter case, after excision of a right-sided meningocele in a 48-year-old woman, when an empyema developed. The world literature on the subject is further listed in Table $I$.

The cases reported here appear to be the 27th and 28th in the world literature. Of the 26 previously found, four cases were described only by brief mention, and most details are not available. These incomplete cases were the one personally communicated by Freelander, and that

\section{TABLE I}

PREVIOUSLY REPORTED CASES OF INTRATHORACIC MENINGOCELE

\begin{tabular}{|c|c|c|c|c|c|c|}
\hline Author & Sex & Age & Side & $\begin{array}{l}\text { Cutaneous } \\
\text { Neuro- } \\
\text { fibromata }\end{array}$ & $\begin{array}{c}\text { Site } \\
\text { of } \\
\text { Origin }\end{array}$ & Remarks \\
\hline Pohl (1933) & F & 47 & Right & Yes & D3-4 & Died, empyema \\
\hline $\begin{array}{l}\text { Schüller and } \\
\text { Uiberall } \\
\text { (1938) }\end{array}$ & $\mathbf{M}$ & 56 & ," & ", & D7-8 & Died \\
\hline Ameuille $e t$ & $\mathbf{F}$ & 48 & , & No & D8-9 & Died, empyema \\
\hline $\begin{array}{l}\text { Campos } \\
\text { Co46) }\end{array}$ & $\mathbf{M}$ & 7 & ," & ," & D5-6 & \\
\hline & $\mathbf{M}$ & 54 & & Yes & D5-6 & \\
\hline $\begin{array}{l}\text { Welch et al. } \\
\text { (1948) }\end{array}$ & $\mathbf{F}$ & 41 & Left & $"$ & D6-7 & \\
\hline $\begin{array}{l}\text { Mendelsohn } \\
\text { and Kay } \\
\text { (1949) }\end{array}$ & $\mathbf{F}$ & Midd & $\begin{array}{l}\text { Right } \\
\text { dle age }\end{array}$ & ", & $\begin{array}{l}\text { D7-8 } \\
\text { (No furt } \\
\text { person } \\
\text { tion by }\end{array}$ & $\begin{array}{l}\text { her information; } \\
\text { tal communica- } \\
\text { y Freelander) }\end{array}$ \\
\hline & & furth & er ca & seen incide & tally at ne & ecropsy by Kay \\
\hline Byron et al. & $\mathbf{F}$ & 36 & Right & Yes & D2-3 & \\
\hline (1949) & $\begin{array}{l}\mathbf{M} \\
\mathbf{M}\end{array}$ & $\begin{array}{l}21 \\
61\end{array}$ & ", & $\begin{array}{l}\text { No } \\
\text { Yes }\end{array}$ & $\begin{array}{l}\text { D1-2 } \\
\text { C7-D1 }\end{array}$ & Died, haemor- \\
\hline Head (1949) & $\mathbf{M}$ & 43 & Left & No & \multicolumn{2}{|c|}{$\begin{array}{l}\text { Diagnosis mechanical. } \\
\text { No further information }\end{array}$} \\
\hline $\begin{array}{l}\text { Cross et al. } \\
\text { (1949) }\end{array}$ & $\mathbf{M}$ & 23 & Right & Yes & $\begin{array}{l}\text { T8-9 } \\
\text { T10-11 }\end{array}$ & 3 meningoceles \\
\hline Kessel & $\begin{array}{l}\mathbf{F} \\
\mathbf{F}\end{array}$ & $\begin{array}{r}23 \\
8\end{array}$ & $\begin{array}{l}\text { Left } \\
\text { Right }\end{array}$ & ", & D5-6 & Died, paraplegia \\
\hline Ottani(1951) & & & No & $11 \mathrm{~s}, \mathrm{p}$ & ed by asp & piration only \\
\hline $\begin{array}{l}\text { Ciaglia } \\
\text { (1952) }\end{array}$ & $\mathbf{F}$ & 31 & Left & Yes & C7-D1 & \\
\hline $\begin{array}{l}\text { Rubin and } \\
\text { Strate- } \\
\text { meier } \\
\text { (1952) }\end{array}$ & (Infa & $\begin{array}{l}7 / 52 \\
\text { nt) }\end{array}$ & Right & No & D4-5 & $\begin{array}{l}\text { Died immedi- } \\
\text { ately follow- } \\
\text { ing observa- } \\
\text { tion }\end{array}$ \\
\hline $\begin{array}{l}\text { Baker and } \\
\text { Curtis } \\
(1953)\end{array}$ & $\begin{array}{l}\mathbf{F} \\
\mathbf{M}\end{array}$ & $\begin{array}{l}40 \\
63\end{array}$ & $\begin{array}{l}\text { Left } \\
\text { Right }\end{array}$ & $\begin{array}{l}\text { Yes } \\
\text { No }\end{array}$ & $\begin{array}{l}\text { D8-9 } \\
\text { D9-10 }\end{array}$ & $\begin{array}{l}\text { Died } 7 \text { months } \\
\text { later }\end{array}$ \\
\hline $\begin{array}{l}\text { Sears et al. } \\
(1953)\end{array}$ & $\mathbf{F}$ & 29 & Left & ", & D2-3 & \\
\hline $\begin{array}{c}\text { Turunen } \\
(1953)\end{array}$ & $\mathbf{M}$ & 33 & " & Yes & D5-6 & \\
\hline $\begin{array}{r}\text { Hackensell- } \\
\text { ner (1953) }\end{array}$ & $\mathbf{F}$ & 45 & Right & " & D8-9 & $\begin{array}{l}\text { Died after } \\
\text { radiotherapy }\end{array}$ \\
\hline $\begin{array}{l}\text { Portigliatti- } \\
\text { Barbos } \\
\text { (1953) }\end{array}$ & $\mathbf{F}$ & 60 & " & " & D6-7 & $\begin{array}{l}\text { Died after } \\
\text { coughing } \\
\text { bout }\end{array}$ \\
\hline $\begin{array}{l}\text { Gernez- } \\
\text { Rieux and } \\
\text { Lepaul } \\
\text { (1954) }\end{array}$ & $\mathbf{M}$ & 59 & ", & No & D11-12 & \\
\hline
\end{tabular}


seen incidentally by Kay (Mendelsohn and Kay, 1949), the case of Head, diagnosed by puncturing the cyst and lumbar puncture, the aspiration of one relieving pressure in the other (Byron, Alling, and Samson, 1949), and Ottani's (1951) case, which was proved by aspiration. In addition, the two cases described by Campos (1946), although almost certain from description, were not proved by any of the diagnostic means or operation or necropsy.

The high incidence of von Recklinghausen's disease in this rare condition has been noted by most authors. The first new case reported appears to be only the eighth in which it was definitely not present (three cases not mentioned). Table II shows the incidence of von Recklinghausen's disease, and side of the meningocele.

TABLE II

DISTRIBUTION OF CASES OF INTRATHORACIC MENINGO. CELE AND INCIDENCE OF VON RECKLINGHAUSEN'S DISEASE

\begin{tabular}{|c|c|c|c|}
\hline & & Left & Right \\
\hline $\begin{array}{l}\text { Males with von Recklin } \\
\text { disease } \\
\text { Males without von } \\
\text { hausen's disease } \\
\text { Females, with von } \\
\text { hausen's disease } \\
\text { Females without von } \\
\text { hausen's disease }\end{array}$ & $\begin{array}{l}\text { nghausen's } \\
\text { Reckling- } \\
\text { Reckling- } \\
\begin{array}{l}\ldots \\
\text { Reckling- } \\
\ldots \quad \ldots\end{array}\end{array}$ & $\begin{array}{l}1 \\
1 \\
4\end{array}$ & $\begin{array}{l}3+1 \text { bilateral } \\
4 \\
6+1 \text { female with von } \\
\begin{array}{l}\text { Recklinghausen's } \\
\text { disease, ? side }\end{array} \\
\begin{array}{l}1+1 \text { right sided without } \\
\text { von Recklinghausen's } \\
\text { disease, ? sex }\end{array}\end{array}$ \\
\hline Total & . & 7 & $\begin{aligned} 15 & -1 \text { bilateral } \\
& +1 \text { ? side }\end{aligned}$ \\
\hline
\end{tabular}

In 2 cases details completely unknown.

It is therefore striking that 17 out of 28 cases have shown the presence of von Recklinghausen's disease, while in his series of 109 mediastinal tumours, 30 of neurogenic origin, Blades (1946) does not mention any cutaneous neurofibromatosis. Kent, Blades, Valle, and Graham (1944), reviewing 105 neurogenic thoracic tumours, found only four to have von Recklinghausen's disease.

On the other hand, the occurrence of other developmental abnormalities with von Recklinghausen's disease has been well noted by several authors (Thannhauser, 1944 ; Carrière, Huriez, Gervois, and Dupret, 1938). Hagelstam (1946) found 94 cases of spinal deformity in patients with neurofibromatosis, an incidence of 7 to $20 \%$ in the various series reviewed; these were mostly scoliosis or kyphoscoliosis, and only two had spinal nerve tumours. One of these had eroded the spinal nerve foramen, the other the neural arch, but neither was cystic. Kessel (1951), quoting
TABLE III

INCIDENCE OF SKELETAL CHANGES IN IN TRATHORACIC MENINGOCELE

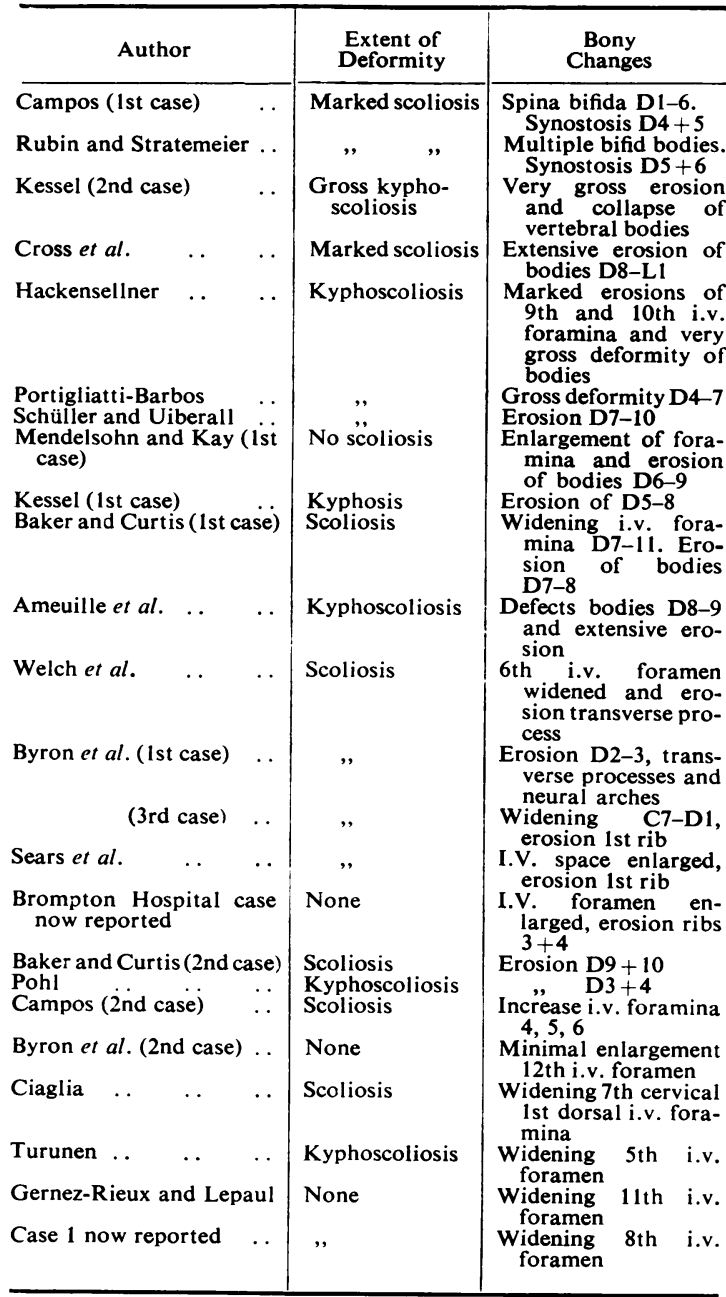

4 cases insufficiently described.

the incidence of neurofibromatosis as 1 in 200 persons, says that $10 \%$ of these show skeletal changes, half of them involving the spine. Table III shows in more detail the extent of bony deformities noted in the 28 cases of intrathoracic meningocele.

In this table an attempt has been made to show the gradation of bony changes from most extensive to minimal. Hypotheses as to the aetiology of the meningocele have ranged between the suggestion of a primary bone deficiency and that of a primary neural abnormality. The cases of Campos (first case) (1946) and Rubin and 
Stratemeier (1952) certainly show congenital bony changes through which meningoceles have appeared. The synostoses reported cannot be considered as secondary to the existence of a meningocele. Likewise, the second case of Campos (1946) and that of Ciaglia (1952) showed widening of several intervertebral foramina, although in each case only one meningocele occurred. The absence of any changes in the vertebral bodies between these foramina indicates that the deficiencies must be congenital rather than secondary to the pressure of the tumour. In contrast, the case described by Cross, Reavis, and Saunders (1949) showed a meningocele at each of the three widened foramina, the ninth and tenth on the right, and the tenth on the left. The widening of several intervertebral foramina described by Hackensellner (1953) and Mendelsohn and Kay (1949) (first case) is associated with erosion of the adjacent bodies and can be considered to be secondary to the existence of the meningoceles. The "hollowing out" of the lateral aspects of vertebral bodies and widening of intervertebral foramina seen in these cases, with more or less full preservation of the full upper and lower articulating edges of the bodies, is similar to that not uncommonly seen in erosion due to neural tumours or aneurysms. Baker and Curtis' (1953) first case would seem to fall between these two groups; the seventh to eleventh foramina were enlarged, while only the bodies of D7 and 8 were eroded. The widened tenth and eleventh foramina were not directly related to the meningocele and must be assumed to be primary; the others may be primary, or secondary to the presence of the tumour. Finally, it should be remembered that, elsewhere in the vertebral column, meningoceles, although always associated with a bony deficiency, do not invariably arise where there is a congenital patency.

Such specimens as have been submitted to histopathological examination have furnished no evidence in support of a primary neural pathology. A spinal block above the level of the meningocele was noted by Schüller and Uiberall (1938), and in the first case of Byron and others (1949), a large protrusion through the coalesced rightsided second and third foramina, there was noted to be a small intraspinal cyst at the inferior aspect of D7. The latter considered that the meningocele may arise at points of congenital weakness in the dura, as in the cases of extradural spinal cysts described by Cloward and Bucy (1937). A commonly suggested mechanism of production is that an abnormal prolongation of the dura develops along the line of the intercostal nerves towards the myotomes, forming a potential space. Further to this Sengpiel, Ruzicka, and Lodmell (1948), whose case is also Byron and others' second case, observed that coughing, straining, etc., may raise the intrathoracic pressure to as much as $100 \mathrm{~mm}$. $\mathrm{Hg}$, and it may then drop to a negative pressure. The intraspinal pressure follows this after a "lag period," so that, at the end of "coughing," there is a moment when thoracic pressure is low and that of the potential cyst high. This tends to distend the cyst. The most striking objection to this hypothesis is noted in the cases reported by Welch, Ettinger, and Hecht (1948), Mendelsohn and Kay (1949), and Turunen (1953), and also in the first case reported here, that the associated intercostal nerve lay distinct from the meningocele right back into the spinal column, and that the dural covering of the meningocele arose intraspinally quite distinctly from the nerve. Cross and others (1949) attempt to combine neural and bony changes in another manner, by suggesting that a primary defect in the closure of the dura at an early age leads to hypoplasia of adjacent bone, which is prolonged through the period of growth, leading to the appearance of a meningocele. The coincidence of primary dural abnormality with primary bony abnormality seems the inescapable conclusion as to aetiology.

The diagnosis of the condition can easily be ascertained, but its rarity has usually led to diagnosis being at operation or death. The radiological appearances and clinical findings, if any, will suggest a thoracic neurofibroma. Radiotranslucency, particularly in tomograms, cannot be considered diagnostic, since neurofibromata may undergo cystic change. Lumbar puncture at the same time as needling of the cyst, and the noting of a fall and rise in pressure between the two when one is aspirated (Head, 1949), seems an unnecessarily complicated method. Simple aspiration of the cyst will yield a fluid cytologically and biochemically similar to cerebrospinal fluid. Artificial pneumothorax and thoracoscopy, as used by Ameuille and others, necessitate a delay of several days between induction and establishment of the diagnosis. Unless thoracoscopy is included, the procedure may not exclude neurofibroma. Myelography, preferably with heavy contrast medium, posturing the cyst dependently, or pneumomyelography, posturing the cyst above the spinal cord, is briefer, reliable, and safe. As stated before, diagnosis is not difficult once the condition has been considered. 
The question of whether surgery should be undertaken, once highly controversial, may be said to be resolving undoubtedly in the affirmative. If the diagnosis has not been made from that of neurofibroma, thoracotomy will almost certainly be proposed because of the malignant change recognized in some neurofibromata ; Noguera and Stupenengo (1951), reviewing the cases of Campos, comment upon the resemblance of meningoceles to intrathoracic neoplasms. The justifications for surgical excision would seem to be the danger of progressive symptoms, bony changes, or even death.

Meningoceles undoubtedly enlarge. The case of Ameuille and others (1940) progressed from radiological invisibility to $8 \mathrm{~cm}$. diameter in 11 years, that of Turunen (1953) increased in size during two months' observation. The meningoceles found in Byron and others' (1949) second case and that of Ciaglia (1952) were likewise not noted radiologically two years previously. Most striking was the first case described by Byron, which enlarged to about three times its first noted volume in five years, causing progressively more severe dyspnoea after four years. Schüller reported intense intercostal pain requiring neurectomy, and, although it is doubtful that the whole bony derangement of Kessel's second case, causing paraplegia and death, was secondary to the presence of a meningocele, there would seem to be good reason for proposing surgical treatment before bony defor-

TABLE IV

SURGICAL EXCISION OF MENINGOCELES

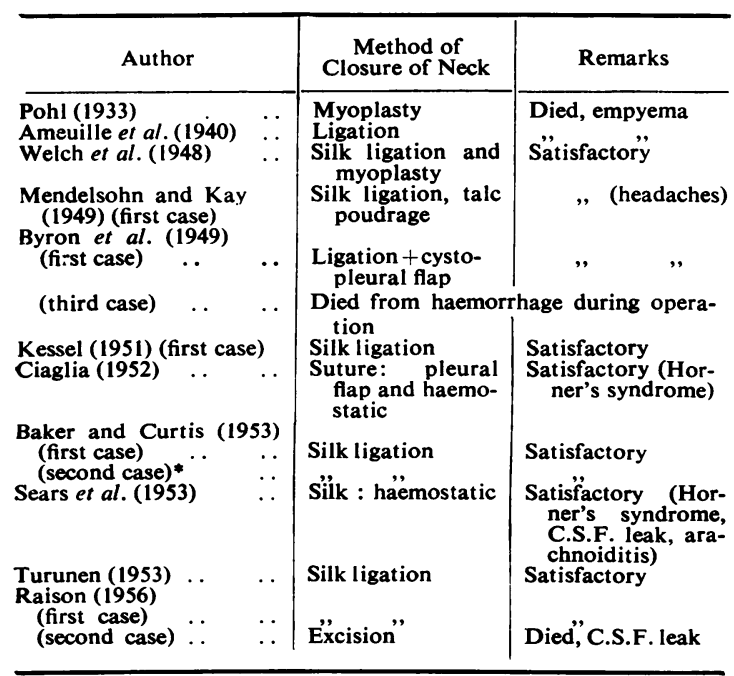

* The case reported by Baker and Curtis died of Paget's disease seven months after successful operation. mity becomes severe. Another indication for early operation would seem to arise from Byron's third case, where erosion and fibrosis had proceeded so far as to render necessary surgery so hazardous as to be fatal. Portigliatti-Barbos (1953) reported the only case of death due to rupture of an intrathoracic meningocele after a bout of very intense coughing. Lesser symptoms have been chest pain, vague (Mendelsohn and Kay, 1949) or more severe (Turunen, 1953), chronic cough (Baker and Curtis, 1953), or loss of posterior column conduction (Kessel, 1951). Table IV shows the outcome of cases treated surgically.

Four deaths have occurred in 14 cases where removal of the meningocele has been attempted. (There is no evidence to support Cross and others (1949), who mention five operative deaths in a review which does not contain the one reported here.) The minor symptoms of headache in the cases of Mendelsohn and Kay (1949) and Byron and others (1949), with some persistence of temperature in the latter, were not sufficient to delay convalescence. The suggestion has been made, as a result, that the patients should be nursed flat post-operatively lest the headaches are due to lowering of cerebrospinal pressure. Leakage of cerebrospinal fluid into the pleural cavity, associated with arachnoiditis, reported by Sears would seem a potentially more serious complication, fatal in the cases of Pohl (1933), Ameuille and others (1940) and the second reported here, which developed empyemas, but these cases were not covered by chemotherapy nor was the possibility of leakage recognized. The occurrence of a postoperative Horner's syndrome noted by Ciaglia (1952) and Sears, Clayton, and Siebel (1953) must primarily be related to the position of the tumours.

The greatest contraindication to surgery has been considered to be the difficulty in closing the neck of the excised sac. Pohl (1933), Ameuille and others (1940) and Tudor Edwards, who operated on the second case reported here, had not the advantage of chemotherapy, and were dealing with an ill-understood problem. There seems to be no objection to leaving sufficient of the neck of the sac to obtain an imbricated ligation. Mendelsohn and Kay (1949), noting that the intervertebral enlargement must persist post-operatively, suggest that a further contraindication to surgery is the possibility of recurrence. Their first case was said to show recurrence of the meningocele radiologically on the ninth and 28th days post-operatively but complete regression at one year, though the photograph reproduced suggests doubt about the latter statement. In no other 
cases has recurrence been noted, some having been followed for two or three years after operation.

\section{SUMMARY}

A review of the 26 previously reported cases of intrathoracic meningocele is presented.

Two further cases are added: one treated surgically in 1933 died, in the other meningocele was successfully excised in 1954 .

Aetiology is discussed, but no final conclusions can be drawn; coincident primary neural abnormality and primary bony abnormality have been present in many of the cases, and it is unlikely that the responsibility of these two conditions can be further differentiated.

Surgical treatment is advocated in view of the risks of enlargement or rupture; the risks of failure are considered small in the light of modern technique, nor does recurrence appear likely.

I wish to express my thanks to Dr. E. N. Moyes. Worcester Chest Clinic, who referred the case, and to $\mathrm{Mr}$. R. Abbey Smith, who performed the operation, for permission to report the first case, and to the latter for his stimulating encouragement in the preparation of this report.

The second case was admitted to the Brompton Hospital for Diseases of the Chest under the care of the late Dr. Burrell, operation being performed by the late $\mathrm{Mr}$. Tudor Edwards. I am grateful to the medical committee of that hospital for permission to report it, and to Dr. J. G. Scadding in particular for providing me with the facilities to abstract from the case notes. Dr. D. L. H. Goddard, at one time R.M.O., kindly first drew my attention to the case.

The $x$-ray films were provided by Dr. M. Israelski and the pathological report by Dr. A. P. Prior.

\section{REFERENCES}

Ameuille, P., Wilmoth, P., and Kudelski, C. (1940). Bull. Soc. mid. Hop., Paris, 56, 608.

Baker, J. M., and Curtis, G. M. (1953). West. J. Surg., 61, 209

Blades, B. (1946). Ann. Surg., 123, 749.

Byron, F. X., Alling, E. E., and Samson, P. C. (1949). J. thorac. Surg., 18, 294.

Campos, J. M. Cabello (1946). Bol. Sanat. S. Lucas (S. Paulo), 8, 40.

Carrière, G., Huriez, C., Gervois, M., and Dupret, R. (1938). La gliofibromatose de Recklinghausen. Doin, Paris.

Ciaglia, P. (1952). J. thorac. Surg., 23, 283.

Cloward, R. B., and Bucy, P. C. (1937). Amer. J. Roentgenol., 38,

681.
Cross, G. O., Reavis, J. R., and Saunders, W. W. (1949). J. Neurosurg., 6, 423.

Groedel, F. M. (1936). Röntgendiagnostik in der inneren Medizin, 5th ed., p. 469. Munich.

Gernez-Rieux, C., and Lepaul, G. (1954). J. franc. Mid. Chir. thorac., 8, 633.

Hackensellner, H. A. (1953). Wien. Z. Nervenheilk., 8, 93.

Hagelstam, L.(1946). Acta chir. scand., 93, 169.

Head, J. (1949). In discussion following Byron et al., p. 302

Heuer, G. J. (1929). Arch. Surg. (Chicago), 18, 935.

Ingraham, F. D., et al. (1944). Spina Bifida and Cranium Bifidum: papers reprinted from New Engl. J. Med. with addition of comprehensive bibliography. Harvard University Press, Camcomprehensive bibliograi
bridge, Mass., U.S.A.

Kent, E. M., Blades, B., Valle, A. R., and Graham, E. H. (1944). J. thorac. Surg., 13, 116.

Kessel, A. W. L. (1951). J. Bone Jt Surg., 33B, 87.

Mendelsohn, H. J., and Kay, E. B. (1949). J. thorac. Surg., 18, 124.

Noguera, O.F., and Stupenengo, R. H. (1951). Dia méd., 23, 3882.

Ottani, G. (1951). Ann. Radiol. diagn. (Bologna), 23, 416.

Ottani, G. (1951). Ann. Radiol. diagn.
Pohl, R. (1933). Röntgenpraxis, 5, 641.

Portigliatti-Barbos, M. (1953). Friuli med., 8, 477.

Rubin, S., and Stratemeier, E. H. (1952). Radiology, 58, 552.

Schmorl, G., and Junghanns, H. (1932). Die gesunde und kranke Wirbelsäule im Röntgenbild, p. 122. Thieme, Leipzig.

Schüller, A., and Uiberall, H. (1938). Confin. neurol. (Basel), 1, 312.

Sears, A. D., Clayton, R. S., and Siebel, E. (1953). J. thorac. Surg. 26, 101 .

Sengpiel, G. W., Ruzicka, F. F., and Lodmell, E. A. (1948). Radio$\log y, 50,515$.

Thannhauser, S. J. (1944). Medicine (Baltimore), 23, 105.

Turunen, M. (1953). Acta chir. scand., 106, 299.

Welch, C. S., Ettinger, A., and Hecht, P. L. (1948). New Engl. J. Med., 238, 622 . 